\title{
$\mathrm{CaCO}_{3}$ と $\mathrm{SiO}_{2}$ の 固体反応
}

\author{
柿 谷悟・藤坂 正良
}

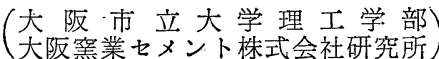

\section{Solid Phase Reaction between Calcium Carbonate and Silica}

By Satoru KAKITANI and Masayoshi FUJISAKA

(Osaka City University, Osaka Yogyo Cement Co. Ltd.)

In order to build up a background to the relative difficulty for burning the different raw materials in cement production the solid phase reactions between $\mathrm{SiO}_{2}$ and either $\mathrm{CaCO}_{3}$ or $\mathrm{BaCO}_{3}$ at the temperatures ranging $500^{\circ} \sim 800^{\circ} \mathrm{C}$ were studied by measuring the amount of $\mathrm{CO}_{2}$ liberated during the reaction. Then, applying the figures so obtained into the Jander's equation for solid phase reaction the authors have tried to work out the rate constants as well as the activation energies. However, it was found out that there were many examples which failed to fit in the equation, probably, due to the additional $\mathrm{CO}_{2}$ liberated by simple thermal dissociation of the carbonates.

On the other hand, W.E.S. Turner et al. have suggested the acceleration of thermal dissociation of $\mathrm{CaCO}_{3}$ when it was mixed with the powder of silica or of pure gold. The same trend was confirmed to exist also in the case of $\mathrm{BaCO}_{3}$.

Furthermore, the investigation of $\mathrm{X}$-ray diffraction pattern has revealed that the reaction products of $\mathrm{CaCO}_{3}$ and $\mathrm{SiO}_{2}$ obtained by heating at $700^{\circ} \mathrm{C}$ in air for 242 hours was not wollastonite $\left(\beta \mathrm{CaO} \cdot \mathrm{SiO}_{2}\right)$ but larnite $\left(\beta 2 \mathrm{CaO} \cdot \mathrm{SiO}_{2}\right)$.

\section{緒言}

$\mathrm{CaCO}_{3}$ と $\mathrm{SiO}_{2}$ の固体反応飞ついては, 古くから また多数の学者によって実験が行われて打り, 熱力学 的な計算や，理論的な取扱いも多くなされてきてい る. 1910 年 J.W. $\mathrm{Cobb}^{1)}$ は $\mathrm{CaCO}_{3}$ と $\mathrm{SiO}_{2}$ の混合 試料を $500^{\circ} \sim 1400^{\circ} \mathrm{C}$ 飞加熱して，その反応生成物江 ついて調べ, 反応は約 $800^{\circ} \mathrm{C}$ で始まることを報告し ている. 1912 年には V.M. Goldschmidt ${ }^{2)}$ が $\mathrm{CaCO}_{3}$ と $\mathrm{SiO}_{2}$ とにより $\mathrm{CaSiO}_{3}$ の生成する変成作用に当っ ての温度一圧力条件に関した知識を導き出している が，A. Danielsson ${ }^{3)} 1950$ 年に修正された熱力学 的数值を用いて，この反応の熱力学的な問題を再吟味 し，1気圧の $\mathrm{CO}_{2}$ の下では自由エネルギーの変化が $280^{\circ} \mathrm{C}$ 以上で珪死石 $\left(\mathrm{CaSiO}_{3}\right)$ の生成江有利である ことを見出している. また 1940 年 N.L. Bowen ${ }^{4}$ の 論文には理論的に珪質石灭岩や苦灰岩の変成作用との 関連性についてのベている. 1931 年 W. Jander と E. Hoffmann ${ }^{5}$ は 1927 年に W. Jander ${ }^{6)}$ が導き出 した反応速度の式を用いて主として $\mathrm{BaCO}_{3}$ と $\mathrm{SiO}_{2}$ の反応速度を計算し, 速度定数招よび活性化エネルギ 一を算出している. 1932 年 W.E.S. Turner ${ }^{7}$ らは $\mathrm{CaCO}_{3}$ (方解石) と $\mathrm{SiO}_{2}$ (石英) の粉体をモル比で $1: 1,1: 2,1: 3$ の 3 種類に混合した各試料と $\mathrm{CaCO}_{3}$ のみをそれぞれ $700^{\circ}, 750^{\circ}, 800^{\circ} \mathrm{C}$ 亿加熱し, 発生する $\mathrm{CO}_{2}$ の量を測定した結果, $\mathrm{SiO}_{2}$ の混在によ $\sim \tau, \mathrm{CaCO}_{3}$ の熱解離が促進され, さら飞 $\mathrm{SiO}_{2}$ の
混合比を増すと一層熱解離が増大すること，また $\mathrm{SiO}_{2}$ のかわりと珪線石や純金の粉末を混合しても同様に $\mathrm{CaCO}_{3}$ の熱解離が促進されることを報告している・最 近, 小松和蔵 ${ }^{81}$ は固体粒子間の反応は，その接触点か ら始まり反応速度はこの点の数に比例するものとして 拡散括よび表面律速の場合について速度式を導出して いる.

他面, $\mathrm{CaCO}_{3}$ と $\mathrm{SiO}_{2}$ の相互反応はセメント, 耐火 物その他の䉑業品の製造呿よび製鉄過程の主体をなす ものであって, 工業的にもこの反応の進行状態につい て詳細な検討が必要であり，また特に比較的低温に括 けるこの系の反応は，接触鉱床その他に招ける珪灰石 の生成機構と関連して地質学的にも大きな意義がある ものと考えられる.

そこで, まず W. Jander と E. Hoffmann の行っ た実験に做って, $\mathrm{CaCO}_{3}$ と $\mathrm{SiO}_{2}$ 拈よび $\mathrm{BaCO}_{3}$ と $\mathrm{SiO}_{2}$ の反応速度定数扣よび活性化エネルギーを求め るため数多くの実験を行ったが, W.E.S. Turner ら が指摘した $\mathrm{CaCO}_{3}$ の熱解離が $\mathrm{SiO}_{2}$ や金粒子の混在 そよって大きくなることを再確認する結果となった・ かつて W. Jander と E. Hoffmann が速度定数招よ び活性化エネルギーを求めた実験は $\mathrm{BaCO}_{3}-\mathrm{SiO}_{2}$ 系 に関するものであるが， $\mathrm{BaCO}_{3}$ に純金粒子を混じた 場合飞る発生する $\mathrm{CO}_{2}$ が多くなり, $\mathrm{BaCO}_{3}$ の熱解離 を促進するものと考光られ, さらに W, Jander と E. Hoffmann が行ったと類似の方法によって得た焼 
成物に関して詳細なX線的検討の結果では，予期した 珠灰石の生成は認められず, ラルン石，( $\left.\beta \cdot 2 \mathrm{CaO} \cdot \mathrm{SiO}_{2}\right)$ の生成が確認された.

\section{I. 実験装置と準備}

まず W. Jander と E. Hoffmann の使用した実験 装置と倣って Fig. 1 と示すような装置を組立てた.

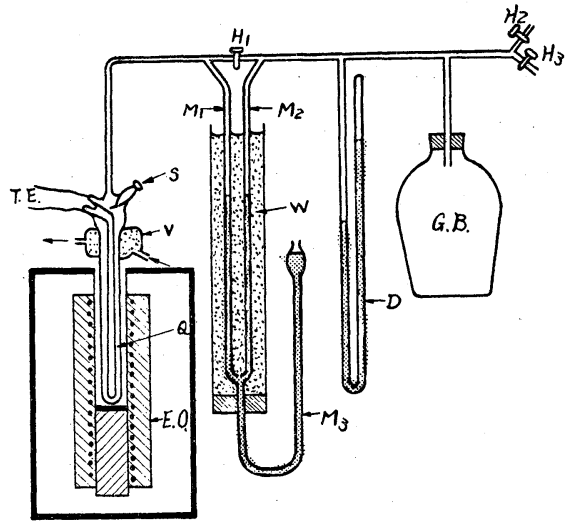

E.O.; Electric furnace, $Q$; Silica glass tube

$T . E$.; Thermocouple, $S$; Glass-cap

G.B.; Glass bottle of 10 litres

$M_{1}, M_{2} ;$ Burette

$M_{3} ;$ Bottle of mercury

$W$; Cooling water

$H_{1}, H_{2}, H_{3}$; Plug

$V$; Pipe of cooling water

Fig.1 Schematic representation of apparatus.

実験飞供した $\mathrm{CaCO}_{3}$ 招よび $\mathrm{BaCO}_{3}$ とは Merck 社 の製品, $\mathrm{SiO}_{2}$ とは特級の非晶質珪酸 および選別した オッタワ石英砂の 粉末を用い, $0.088 \sim 0.044 \mathrm{~mm}$ の 標準穊を通した。な招試料は $120^{\circ} \mathrm{C} て ゙ 2$ 時間乾燥し て湿分を除いた．金粒子は純度 $99.9 \%$ のるのを $44 \mu$ 以下と $88 \mu$ 以下の 2 つと分けて使用した.

混合試料をつくるには, まず所期のモル比に科量し た試料と土チルアルコールまたはアセトンを滴下して 湿式でよく混和した後, 電気乾燥器に入れて揮発性液 体を完全に駆遂する。このようとして調整した混合試 料 $0.1 \mathrm{~g}$ 不は $0.2 \mathrm{~g}$ を科量して内径 $0.7 \mathrm{~cm}$, 深さ 1.3 $\mathrm{cm}$ の白金血飞入れ, Fig. 1 と示してある電気炉の (S) の部分の先端に吊し, 気圧はあらかじめ実験を行 い, 発生する $\mathrm{CO}_{2}$ の容積から適当であると解った気圧 飞定め, 電気炉の温度を調節して所定温度飞安定後, コ ック $(S)$ を趈して試料皿を石英管 $(Q)$ の中に落下さ せ, 反応の進行之共に発生する $\mathrm{CO}_{2}$ の容積を $\left(M_{1}\right)$ の目盛付ガラス管で語みとる。 この場合発生する $\mathrm{CO}_{2}$ の容積変化を気圧一定のもとで測る目的で, $\left(M_{1}\right)$, $\left(M_{2}\right)$ の水銀柱の高さが常飞同一の高さを保つようと 水銀溜 $\left(M_{3}\right)$ を上下操作しながら $\mathrm{CO}_{2}$ の容積を読 みとった，気圧は 水銀圧力計 $(D)$ で読みとり, $\mathrm{CO}_{2}$ の温度は $\left(M_{1}\right),\left(M_{2}\right)$ を取り团む水柱 $(W)$ の温度を
測って知り, 標準状態 $\left(0^{\circ} \mathrm{C}, 1\right.$ 気圧 $)$ の $\mathrm{CO}_{2}$ の容積 飞換算した.

また反応生成物は偏光顕微鏡と理学電機製作の X線 回折計数装置によって検討した。

\section{II. 実 験 結 果}

A) $\mathbf{C O}_{2}$ の容積の測定 Fig. 1 亿示した実験装置 を用いて，種々の混合比と招ける $\mathrm{CaCO}_{3}$ と $\mathrm{SiO}_{2}$, $\mathrm{BaCO}_{3}$ と $\mathrm{SiO}_{2}$ 及び $\mathrm{BaCO}_{3}$ と純金粒子の混合試料飞

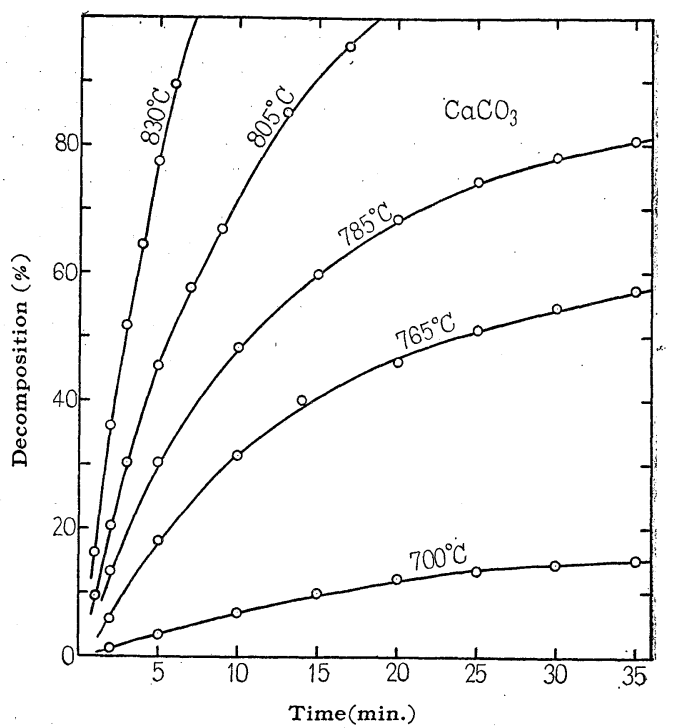

Fig.2 (a) The rate of decomposition of calcium carbonate at various temperatures in air $(663 \mathrm{mmHg})$

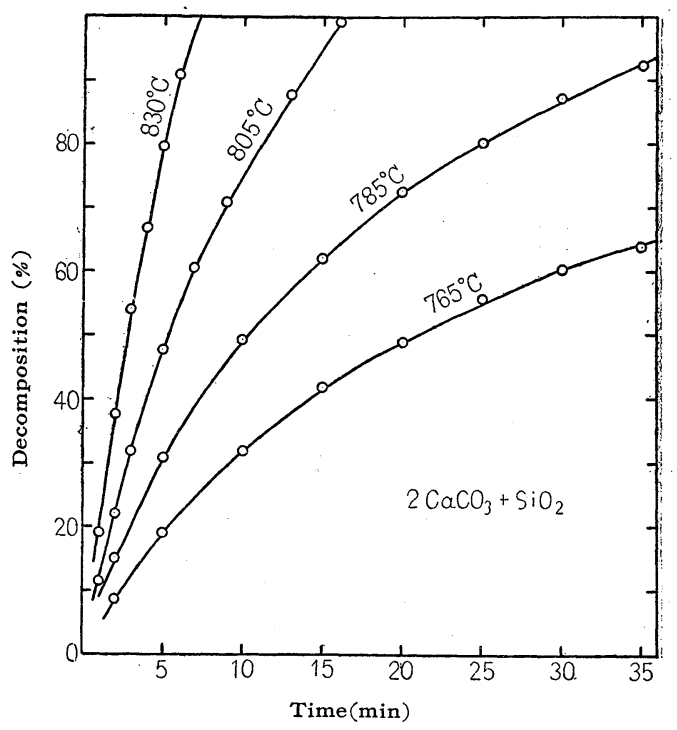

Fig.2 (b) The rate of decomposition of calcium: carbonate in presence of quartz at various temperatures in air $(663 \mathrm{mmHg})$. 
ついて，それぞれ所定の温度のもと飞発生する $\mathrm{CO}_{2}$ の容皘を測定し，これを $\mathrm{CaCO}_{3}$ 抽よび $\mathrm{BaCO}_{3}$ が完 全熱解離したときの容積依対する百分率 $(\%)$ であら わした.

(1) $\mathrm{CaCO}_{3}$ のみ, または $\mathrm{CaCO}_{3}$ と $\mathrm{SiO}_{2}$ の混合 試料を $0.1 \mathrm{~g}$ 秤量し, $663 \mathrm{mmHg}$ の気圧のもとで発生 する $\mathrm{CO}_{2}$ の容積を測定.

Fig. 2 (a) は $\mathrm{CaCO}_{3}$ を $700^{\circ}, 765^{\circ}, 785^{\circ}, 805^{\circ} \mathrm{C}$ 招

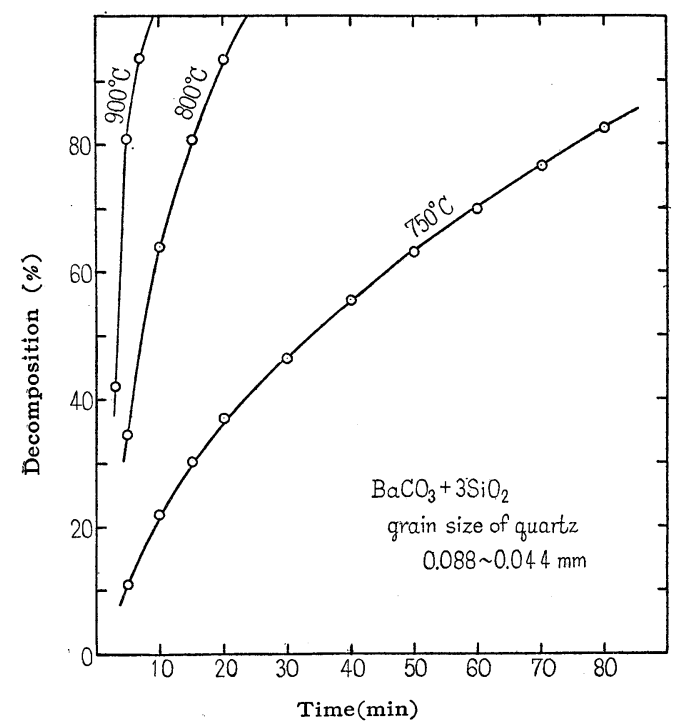

Fig.3 (a) The rate of decomposition of barium carbonate in presence of quartz at various temperatures in air $(517 \mathrm{mmHg})$, (gain size of quartz $=0.088 \sim 0.044 \mathrm{~mm}$ ).

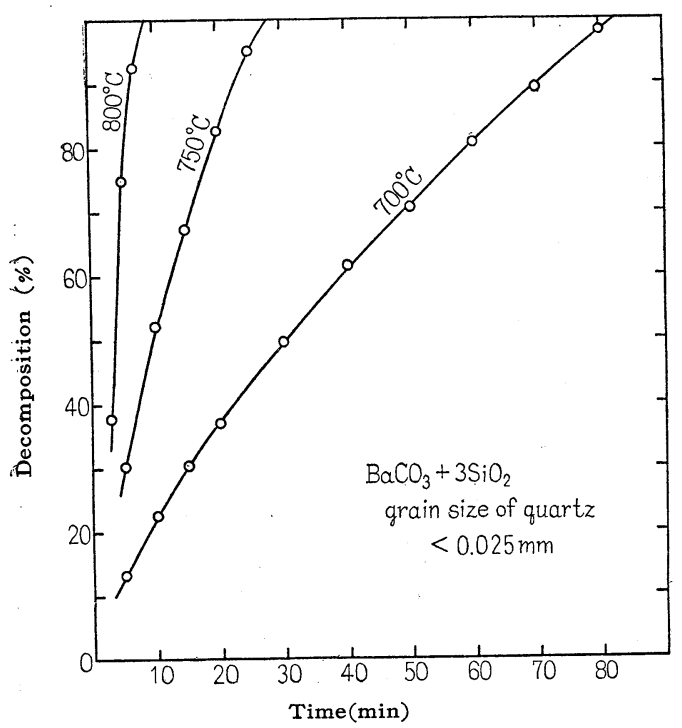

Fig.3 (b) The rate of decomposition of barium carbonate in presence of quartz at various temperatures in air $(517 \mathrm{mmHg})$, (grain size of quartz $<0.025 \mathrm{~mm}$ ).
よび $830^{\circ} \mathrm{C}$ と加熱したとき，Fig. 2 (b) は $\mathrm{CaCO}_{3}$ : $\mathrm{SiO}_{2}$ (石英) $=2: 1$ のモル比混合した試料を $765^{\circ}$, $785^{\circ}, 805^{\circ} \mathrm{C}$ 抢よび $830^{\circ} \mathrm{C}$ の各温度に加熱したとき, 経過時間飞伴なろ熱解離（\%) を示したるのである.

$830^{\circ} \mathrm{C}$ と $805^{\circ} \mathrm{C}$ の場合は $\mathrm{SiO}_{2}$ が混在しても熱解 離とあまり違いがないが, $785^{\circ} \mathrm{C}$ と $765^{\circ} \mathrm{C}$ では $\mathrm{SiO}_{2}$ が混在する場合に, 熱解離が目立って大きい。

(2) $\mathrm{BaCO}_{3}$ と $\mathrm{SiO}_{2}$ の混合試料を $0.2 \mathrm{~g}$ 科量し, $517 \mathrm{mmHg}$ のるとで発生する $\mathrm{CO}_{2}$ の容積を測定.

W. Jander と E. Hoffmann は $\mathrm{CaCO}_{3}$ より比較的 熱炕対して安定な（解離温度の高い） $\mathrm{BaCO}_{3}$ を用い て, $\mathrm{SiO}_{2}$ との固体反応飞よって発生する $\mathrm{CO}_{2}$ を測っ て反応速度を論じているので，ここでも $\mathrm{CaCO}_{3}$ の場 合と同様に $\mathrm{BaCO}_{3}$ 飞対する $\mathrm{SiO}_{2}$ (石英粒子) の影 響を検討した。

Fig. 3 (a) $\mathrm{BaCO}_{3}: \mathrm{SiO}_{2}$ (石英の粒径 0.088 $0.044 \mathrm{~mm})=1: 3$ モル比の混合試料を $750^{\circ}, 800^{\circ} \mathrm{C}$ 打 よび $900^{\circ} \mathrm{C}$ 飞加熱したとき. Fig. 3 (b) は $\mathrm{BaCO}_{3}$ : $\mathrm{SiO}_{2}$ (石英の粒径 $0.025 \mathrm{~mm}$ 以下) $=1: 3$ モル比の混 合陚料を $700^{\circ}, 750^{\circ} \mathrm{C}$ 招よび $800^{\circ} \mathrm{C}$ 亿加熱したときの $\mathrm{BaCO}_{3}$ の熱解離 $(\%)$ と時間との関係を示したるの である. Fig. 3 の両図より $\mathrm{BaCO}_{3}$ と混ずる $\mathrm{SiO}_{2}$ (石 英)の粒径を小さくすると $\mathrm{BaCO}_{3}$ の熱解離が非常飞 大きくなることが明らかである.

(3) $\mathrm{CaCO}_{3}$ と金粒子の混合試料を $0.1 \mathrm{~g}$ 科量し， $613 \mathrm{mmHg}$ の気压のもとで発生する $\mathrm{CO}_{2}$ の容積を測 定.

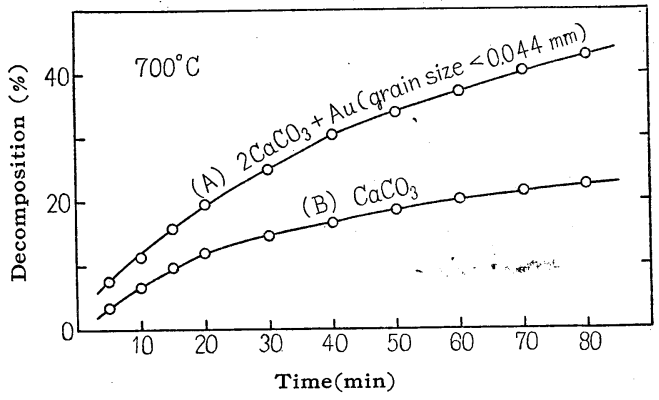

(A) : $2 \mathrm{CaCO}_{3}+\mathrm{Au}$ (grain size of gold $<0.044 \mathrm{~mm}$ ), (B): $\mathrm{CaCO}_{3}$

Fig. 4 The rate of decomposition of barium carbonate in presence of gold grain at $700^{\circ} \mathrm{C}$ in air $(663 \mathrm{mmHg})$

Fig. 4 中の $\mathrm{A}$ 曲線は $\mathrm{CaCO}_{3}$ : Gold (金の粒径は $0.044 \mathrm{~mm}$ 以下) $=2: 1$ モル比の混合試料を, また $\mathrm{B}$ 曲線は比較のためと $\mathrm{CaCO}_{3}$ のみを，それぞれ $700^{\circ} \mathrm{C}$ そ加熱したとき経過時間飞伴な弓熱解離（\%)の変化 を示したものである．この図から金粒子の混在に括い て $\mathrm{CaCO}_{3}$ の熱解離が大い促進されることが明らか である.

(4) $\mathrm{BaCO}_{3}$ と金粒子の混合試料を $0.2 \mathrm{~g}$ 秤量し, 
$517 \mathrm{mmHg}$ の気圧のもとで発生する $\mathrm{CO}_{2}$ の容積を測 定.

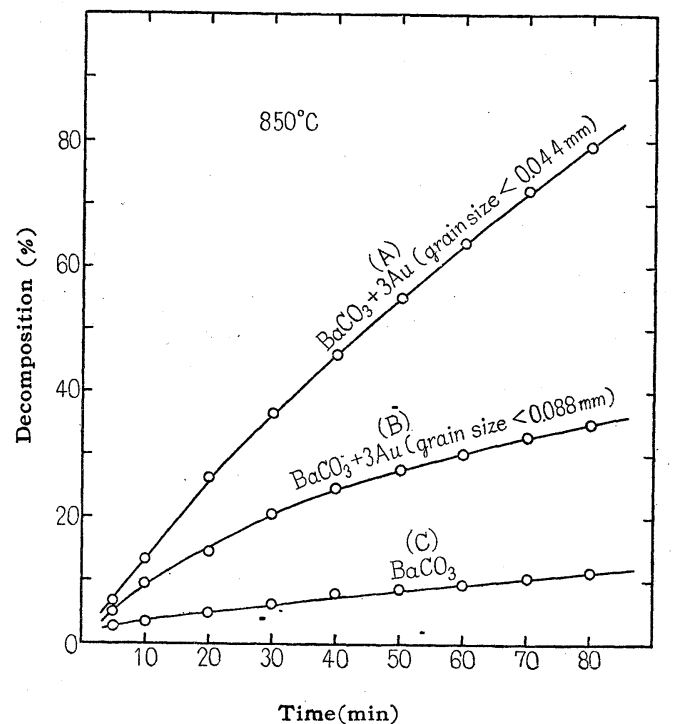

(A): $\mathrm{BaCO}_{3}+3 \mathrm{Au}$, grain size of gold $<0.044 \mathrm{~mm}$.

(B): $\mathrm{BaCO}_{3}+3 \mathrm{Au}$, grain size of gold $<0.088 \mathrm{~mm}$.

(C): $\mathrm{BaCO}_{3}$

Fig.5 The rate of decomposition of barium carbonate in presence of gold grain at $850^{\circ} \mathrm{C}$ in air $(517 \mathrm{mmHg})$.

Fig. 5 中の $\mathrm{A}$ 曲線は $\mathrm{BaCO}_{3}$ : Gold (金の粒径は $0.044 \mathrm{~mm}$ 以下) $=1: 3$ モル比の混合武料. B曲線は $\mathrm{BaCO}_{3}$ : Gold (金の粒径は $0.088 \mathrm{~mm}$ 以下) $=1: 3$ モ ル比の混合試料. C曲線は比較のためと $\mathrm{BaCO}_{3}$ のみ をとれぞれ $850^{\circ} \mathrm{C}$ 飞加熱したときの時間と熱解離(\%) との関係を示したものである. この図より明らかなこ とは $\mathrm{BaCO}_{3}$ 飞 $\mathrm{SiO}_{2}$ を混じた場合ほど顕著ではない が，金粒子を混じてもやほり $\mathrm{BaCO}_{3}$ の熱解離が大い 飞促進されることである.

\section{B） X線回折による焼成物の検討}

(1) $\mathrm{CaCO}_{3}: \mathrm{SiO}_{2}$ (非晶質珠酸) $=2: 1$ モル比の 混合試料.

Fig.6 は $\mathrm{CaCO}_{3}: \mathrm{SiO}_{2}$ (非晶質珪酸) $=2: 1$ モル 比の混合試料を $663 \mathrm{mmHg}$ の気圧中で $550^{\circ} \mathrm{C}, 680^{\circ} \mathrm{C}$ $720^{\circ} \mathrm{C}, 785^{\circ} \mathrm{C}$ の各温度で 30 分焼成した試料のX線回 折図を示しそものである.

(a) $\left(550^{\circ} \mathrm{C}\right.$ 加熱の試料) の回折図では $\mathrm{CaCO}_{3}$ の 回折線の久が強く, $\mathrm{CaO}$ 括よび他の反応生成物の回 折線と思われるるのは明膫でない。

(b) $\left(680^{\circ} \mathrm{C}\right)$ となると $\mathrm{CaO}$ の回折線が割合飞明 膫にでるが，その他のるのはまだ明膫でない。

(c) $\left(720^{\circ} \mathrm{C}\right)$ も $\mathrm{CaO}$ の線ははっきりしている が，その他は明らかでない。

(d) $\left(785^{\circ} \mathrm{C}\right)$ では $\mathrm{CaO}$ の回折線の外际 $\beta 2 \mathrm{CaO}$. $\mathrm{SiO}_{2}$ の線が認められる。 (a)

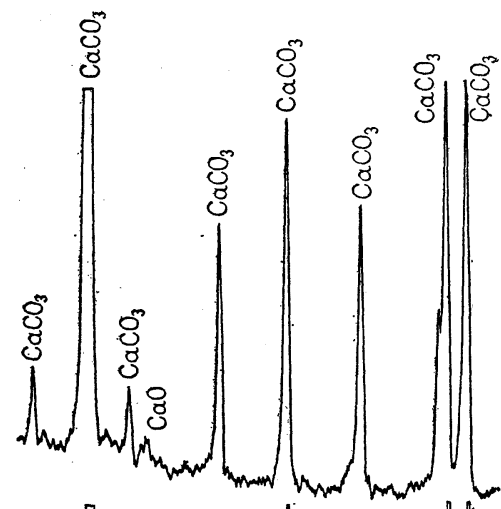

(b)

(c)

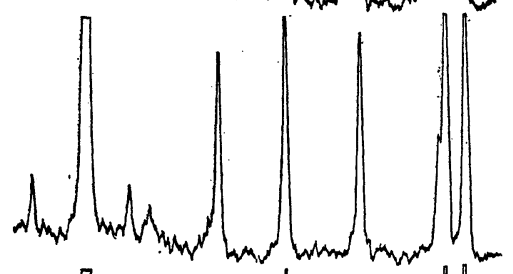

(d)
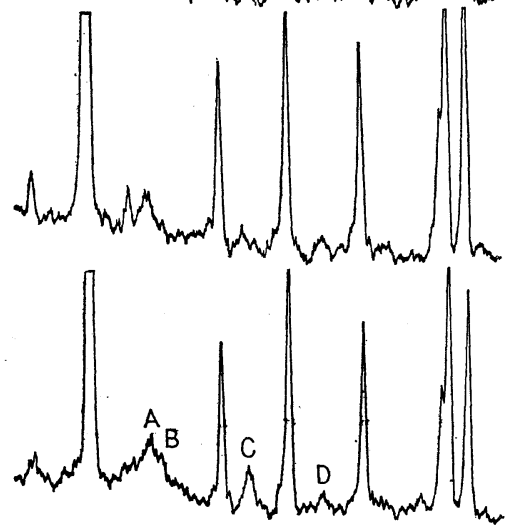

$\begin{array}{cccccc}1 & 1 & 1 & 1 & 1 & 1 \\ 25 & 30 & 35 & 40 & 45 & 50 \\ & & & & & \\ & & & & \end{array}$

Fig.6 X-ray diffraction diagrams of mixture $\left[2 \mathrm{CaCO}_{3}+\mathrm{SiO}_{2}\right.$ (amorphous silica) $]$ heated at various temperatures $\left(550^{\circ}, 680^{\circ}, 720^{\circ}, 785^{\circ} \mathrm{C}\right)$ in air $(663 \mathrm{mmHg})$ for 30 minutes.

この時のX線の使用条件は, $\mathrm{Cu} \mathrm{K}_{\alpha}, 35 \mathrm{kV}, 15 \mathrm{~mA}_{\text {， }}$, Divergence slit; $1^{\circ}$, Receiving slit; $0.1 \mathrm{~mm}, 1^{\circ}$, Scale factor; 4 , Time constant; 8 seconds, Scanning speed; $1^{\circ} 2 \theta$ per minute, Chart speed; $1 \mathrm{~cm}$ per minute である.

(2) $\mathrm{CaCO}_{3}: \mathrm{SiO}_{2}$ (石英) $=2: 1$ モル比の混合試 料.

Fig.7(a) は $\mathrm{CaCO}_{3}: \mathrm{SiO}_{2}$ (石英) $=2: 1$.モル比の. 混合試料を焼成前にとったX線回折図である。

(b) は上記の試料を $663 \mathrm{mmHg}$ の気圧中で 60 分 , $750^{\circ} \mathrm{C}$ 飞加熱したるのの回折図である.

（c）はな扔念のために（b) の試料を X 線の発生条 
Table 1

(a)

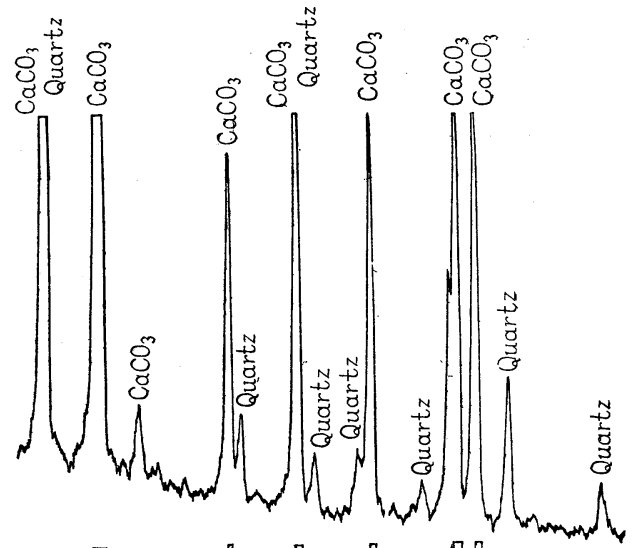

(b)

(c)

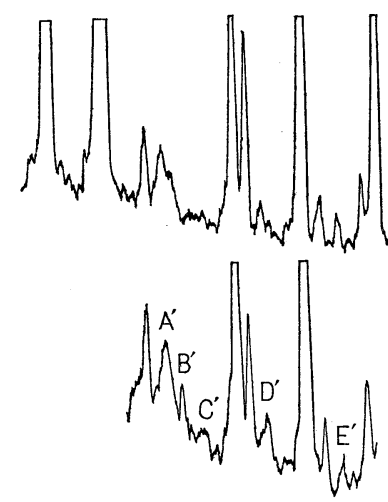

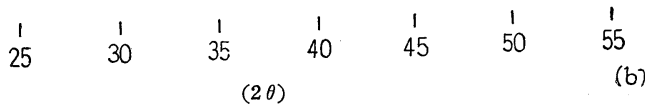

Fig.7 X-ray diffraction diagrams of mixture $\left[2 \mathrm{Ca} \quad \mathrm{CO}_{3}+\mathrm{SiO}_{2}\right.$ (quartz)] preheated and heated at $750^{\circ} \mathrm{C}$ in air $(663 \mathrm{mmHg})$ for 60 minutes.

件を変えてとった図である.

(a), (b) のときのX線発生条件は, $\mathrm{CuK}_{\alpha}, 35 \mathrm{kV}$ $15 \mathrm{~mA}$, Div. slit; $1^{\circ}$, Rec. slit ; $0.1 \mathrm{~mm}, 1^{\circ}$, Scale factor; 4 , Time constant; 8 seconds, scan. speed ; $1 \% \mathrm{~min}$., chart speed $; 1 \mathrm{~cm} / \mathrm{min}$. であり, (c) のときの条件は $\mathrm{CuK}_{\alpha}, 40 \mathrm{kV}, 18 \mathrm{~mA}$, Div. slit; $2^{\circ}$, Rec. slit; $0.2 \mathrm{~mm}, 2^{\circ}$, scale factor 4 , Time constant ; 8 seconds, scan. speed; $1 \% \mathrm{~min}$, chart speed; $1 \mathrm{~cm} / \mathrm{min}$. である.

Fig.6 と Fig. 7 飞示されて岕る回折線のろち $\mathrm{CaCO}_{3}$ と $\mathrm{SiO}_{2}$ 以外の \& の とついて比較のため Table 1 にまとめた。

Table 1 より明らかなように, Fig.5, Fig.6の 場合, いずれる反応生成物は $\beta 2 \mathrm{CaO} \cdot \mathrm{SiO}_{2}$ であ る.

(3) $\mathrm{CaCO}_{3}: \mathrm{SiO}_{2}$ (石英) $=1: 1$ モル比の混合 試料.

$\mathrm{CaCO}_{3}: \mathrm{SiO}_{2}$ (石英の 粒径 $0.017 \mathrm{~mm}$ 以下) $=1$ : 1 モル比の混合陚料を空気申 $700^{\circ} \mathrm{C} \pm 10^{\circ}$ のシリコ.

(d)
$\mathrm{CaCO}_{3}: \mathrm{SiO}$ (amorphous $\quad \mathrm{CaCO}_{3}: \mathrm{SiO}$ (quartz) $=2: 1$ silica) $=2: 1 \quad 663 \mathrm{mmHg}, 750^{\circ} \mathrm{C}, 60$ minutes $663 \mathrm{mmHg}, 785^{\circ} \mathrm{C}, 30$ minutes Peak d $(\AA)$ Peak $\mathrm{d}(\AA)$

A $2.27 \mathrm{CaO}, \beta 2 \mathrm{CaO} \cdot \mathrm{SiO}$

B $2.717 \beta 2 \mathrm{CaO} \cdot \mathrm{SiO}_{2} \quad \mathrm{C}^{\prime} 2.611 \beta 2 \mathrm{CaO} \cdot \mathrm{SiO}_{2}$

C $2.411 \mathrm{CaO}, \beta 2 \mathrm{CaO} \cdot \mathrm{SiO}_{2} \quad \mathrm{D}^{\prime} 2.409 \mathrm{CaO}, \beta 2 \mathrm{CaO} \cdot \mathrm{SiO}_{2}$ D $2.199 \beta 2 \mathrm{CaO} \cdot \mathrm{SiO}_{2} \quad \mathrm{E}^{\prime} 2.196 \beta 2 \mathrm{CaO} \cdot \mathrm{SiO}_{2}$ 鉱物の同定には Bogue の著書の值を参照した. $\left.{ }^{9}\right)$

ニット電気炉中に 242 時間放置し， 1,2,5,11,23,47， $71,95,119,146,170,218,242$ 時間後に取出した試料に ついてふたたびX線回折によって調べた.

14 個の試料より 1 時間, 5 時間, 14 時間, 242 時

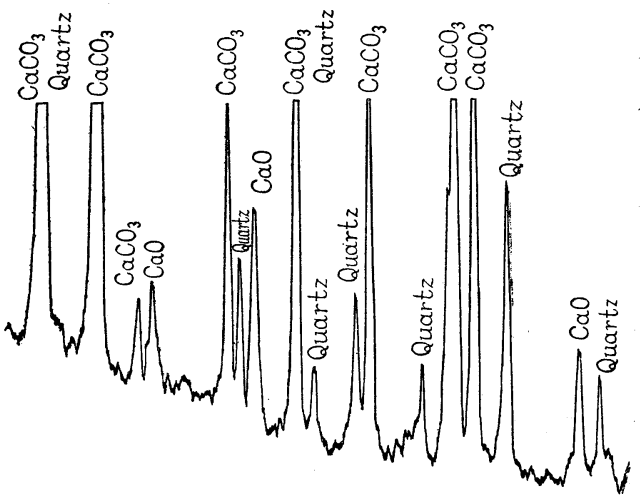

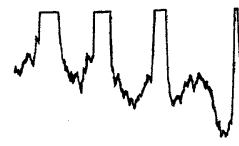<smiles>c1ccccc#1</smiles>

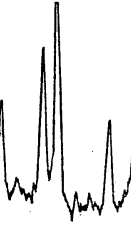

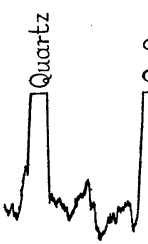

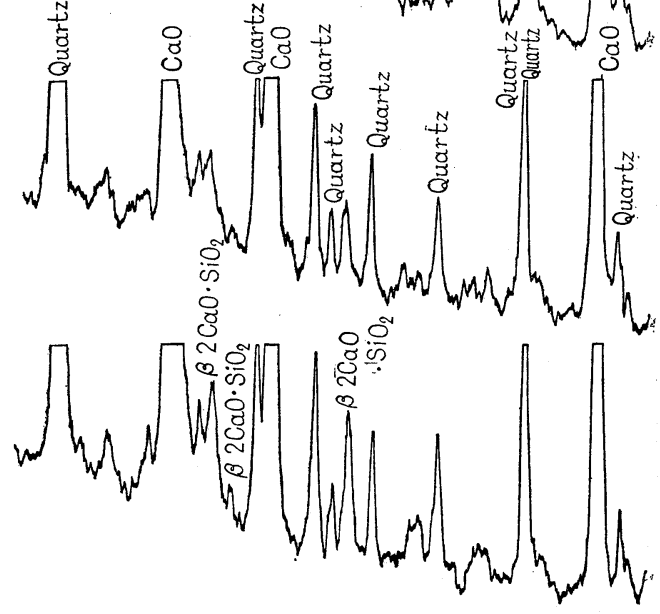

$$
\begin{array}{ccccccc}
1 & 1 & 1 & 1 & 1 & 1 & 1 \\
25 & 30 & 35 & 40 & 45 & 50 & 55 \\
& & & (2 \theta) & & &
\end{array}
$$

Fig. 8 Variation of X-ray diffraction diagrams of mixture $\left[\mathrm{CaCO}_{3}+\mathrm{SiO}_{2}\right.$ (quartz) $]$ heated at $700^{\circ} \mathrm{C}$ in air for various times $(1,5,146,242$ hours). 間後に取り出した 4 個を選んで Fig. 8 と示した.（a), 
は 30 分後に取り出した試料の回折図で $\mathrm{CaCO}_{3}$ と $\mathrm{SiO}_{2}$ (石英) 線以外飞 $\mathrm{CaO}$ の線方現われているかうま だ外の生成物と思われる線はでていない（b)は 5 時 間後に取出した試料の回折図で $\mathrm{CaO}$ 以外にはじめて $\beta 2 \mathrm{CaO} \cdot \mathrm{SiO}_{2}$ の回折線が認められるようになった.

(c) は 146 時間後仅取出した武料の回折図で $\beta 2 \mathrm{CaO}$ $\cdot \mathrm{SiO}_{2}$ の回折線がかなり強くなり, (d) 飞示す 242 時 間後の試料ではな招一層 $\beta 2 \mathrm{CaO} \cdot \mathrm{SiO}_{2}$ の線が顕著に なり, $\beta 2 \mathrm{CaO} \cdot \mathrm{SiO}_{2}$ の結晶が生長しているものと思わ れる。

c) ・焼成物の顕微鏡観察. $\mathrm{CaCO}_{3}: \mathrm{SiO}_{2}$ (石 英) $=1: 1$ モル比の混合試料を $700^{\circ} \mathrm{C}$ で 242 時間㜔成し 適当な時期に一部ずつ取出した前記の試料を顕微鏡下 で観察した.1 時間後に取り出した試料では, $\mathrm{SiO}_{2}$ (石 英）以外飞 $\mathrm{CaCO}_{3}$ の分解してできた $\mathrm{CaO}$ が若干認 められる程度である. 5 時間後に取り出した試料にな ると $\mathrm{CaO}$ の量を増し, 反応生成物を明確に見分ける ことは困難であるが，少し粉体間の膠着が認められ る. 146 時間後の試料になると $\mathrm{CaCO}_{3}$ は消隇してほ とんどすべて $\mathrm{CaO}$ となり, 粉体は大部分膠着してい る. 242 時間後では $\mathrm{CaCO}_{3}$ は完全に $\mathrm{CaO}$ に変って 特り, 反応生成物らしきものもあるが明瞭に鏡下で区 別することが困難である. 粉体は若干集合し膠着して ณる。

\section{III. 実験結果の考察}

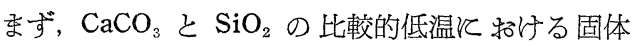
反応の反応速度を究明する目的で, W. Jander と E. Hoffmann の実験に倣い, Jander の反応速度の式を 使って実際実験值を用いて計算を行ったのである が，Jander の反応速度式では説明できない結果が出 たために，その原因を探究するのに行った実験の方が 主体をなすと至った。

ところで, からて J.W. Cobb は $\mathrm{CaCO}_{3}+\mathrm{SiO}_{2}$, $3 \mathrm{CaCO}_{3}+\mathrm{SiO}_{2}, \mathrm{CaCO}_{3}+10 \mathrm{SiO}_{2}$ の混合物を $500^{\circ} \sim$ $1400^{\circ} \mathrm{C}$ 飞加熱し，焼成物を $1 \mathrm{~N} \cdot \mathrm{HCl}$ 括よび $5 \%$ の $\mathrm{Na}_{2} \mathrm{CO}_{3}$ 溶液で抽出し, 可溶性の珪酸を定量して, 両 者の化学反応は約 $800^{\circ} \mathrm{C}$ で始まり, 両者の混合割合 忺無関係にまず $2 \mathrm{CaO} \cdot \mathrm{SiO}_{2}$ が生成することを指摘 几ているし, また W.E.S. Turner らは $\mathrm{CaCO}_{3}$ (方解 石) 扎よび $\mathrm{SiO}_{2}$ (石英) の粉末を $\mathrm{CaCO}_{3}+\mathrm{SiO}_{2}$, $\mathrm{CaCO}_{3}+2 \mathrm{SiO}_{2}, \mathrm{CaCO}_{3}+3 \mathrm{SiO}_{2}$ の割合 $\mathrm{C}$, 又 $\mathrm{CaCO}_{3}$ $+\mathrm{Au}, \mathrm{CaCO}_{3}+2 \mathrm{Au}, \mathrm{CaCO}_{3}+3 \mathrm{Au}$ の混合試料をつ くり, $700^{\circ}, 750^{\circ}, 800^{\circ} \mathrm{C}$ の各温度で加熱して発生す る $\mathrm{CO}_{2}$ の容積を測定し，その焼成物を顕微鏡下で観 嚓してもほとんど反応生成物が認められないところか b. $\mathrm{SiO}_{2}$ (石英) や金の粉末灣 $\mathrm{CaCO}_{3}$ の熱解離を促 進する触媒的な作用をなするの゙であること，また比較
的高温で長時間加熱した混合試料は顕微鏡下でごく微 細な反応生成物が認められ，これを醋酸，塩酸一炭酸 ソーダの溶液で処理すると溶液中に珪酸が溶出し, 反 応生成物として $\mathrm{CaO} \cdot \mathrm{SiO}_{2}$ らしきものが生成してい ると報告しているので, 今一度ここに W. Jander と E. Hoffmann の行った $\mathrm{BaCO}_{3}$ と $\mathrm{SiO}_{2}$ との固体反 応の実験を検討したところ, $\mathrm{BaCO}_{3} \& \mathrm{CaCO}_{3}$ と同様 に金の粒子の混在によって $\mathrm{CO}_{2}$ の発生が非常に多く なり，これは $\mathrm{BaCO}_{3}$ の熱解離が促進される結果と考 えられ, $\mathrm{CaCO}_{3}: \mathrm{SiO}_{2}$ (石英) $=2: 1$ の混合試料を $750^{\circ} \mathrm{C}$ で 60 分加熱して生成されるるのは $\beta 2 \mathrm{CaO}$. $\mathrm{SiO}_{2}$ であり, $\mathrm{CaCO}_{3}: \mathrm{SiO}_{2}$ (石英) $=1: 1$ の混合試 料を $700^{\circ} \mathrm{C}$ で 242 時間加熱し, その間江和ける中間 的生成物についてX線回折によって調べたけれどもい ずれも $\beta 2 \mathrm{CaO} \cdot \mathrm{SiO}_{2}$ で $1180^{\circ} \mathrm{C}$ 以下で安定な $\beta \mathrm{CaO}$. $\mathrm{SiO}_{2}$ (Wollastonite, Triclinic) の生成を認めることが 出来なかった. しかし $800^{\circ} \sim 1000^{\circ} \mathrm{C} て ゙ \mathrm{CaSiO}_{3}$ の組 成のガラスを加熱することとよって $\beta \mathrm{CaO} \cdot \mathrm{SiO}_{2}$ が得 られるだろうという記載 ${ }^{10)}$ はある. $\mathrm{CaCO}_{3}$ と $\mathrm{SiO}_{2}$ の混合物を $700^{\circ} \mathrm{C}$ 前後で $30 \sim 60$ 分 加熱し, 固体反応 によって $\beta 2 \mathrm{CaO} \cdot \mathrm{SiO}_{2}$ が生成しても顕微鏡観察招よ びX線回折の結果からすると，反応生成物の $\beta 2 \mathrm{CaO}$. $\mathrm{SiO}_{2}$ は極く僅かで $\mathrm{SiO}_{2}$ はほとんど減少して招らず, それに対して $\mathrm{CaCO}_{3}$ は多量に分解して $\mathrm{CaO}$ になっ ているのが確認されるので, 発生する $\mathrm{CO}_{2}$ 甶固体反 応による $\mathrm{CO}_{2}$ よりも大部分が熱解離に 基づくのであ ると考学るがよいと思う.

\section{結 言}

以上の実験結果より，W.Jander と E. Hoffmann の行った実験は熱解離に基づく $\mathrm{CO}_{2}$ をも同時に测定 していたことになりまた $\mathrm{CaCO}_{3}$ と $\mathrm{SiO}_{2}$ の混合物 を $700^{\circ} \mathrm{C}$ 前後の”比較的低温度で 30〜60 分加熱した のでは $\beta \mathrm{CaO} \cdot \mathrm{SiO}_{2}$ (Wollastonite) は生成されなく

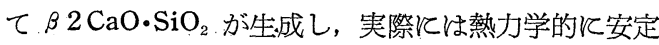
して存在し得ると考光られる反応方程式の通りには反 応が進行しないことが明らかとなった。

すでr W.E.S. Turner $5 か ゙ \mathrm{CaCO}_{3}$ の熱解離は金 粒子によっても促進されることを指摘しているのであ るが, $\mathrm{BaCO}_{3}$ もやほり $\mathrm{SiO}_{2}$ や金の粒子によって熱 解離が促進され, 特飞不活性体である金粒子が固体の $\mathrm{CaCO}_{3}$ のみならず $\mathrm{BaCO}_{3}$ の分解に影響を及ぼすこと 子実証された。

殊飞固体反応飞拓ては，液体や気体の反応とは大 いに趣を異にし，反応が複雑でまた反応の模様が時間 と共決常に変化するので, 反応生成物について充分 な検詩を経なければ，反応速度に関する計算や理論的 な取扱いには過誤を招く危険性のあるものと判断され 
る.

最後に, 本研究の遂行にあたり, 大阪市立大学岩津 潤教授に終始御鞭鞋賜わりました。な括本研究に関し ては, 広島大学教授梅垣嘉治博士に種々御指導いたた きとの上本稿の御校閲を賜わりました。厚く御礼申乙 上げます。

本論文は昭和 32 年 6 月 14 日, 大阪俱楽部で開かれ た窯業協会関西支部例会に括ける講演である。

\section{参考 文 献}

1) J.W. Cobb, J. Soc. Chem. Ind., 26, 250-59 (1910)

2) B.H. Mason, "Principles of Geochemistry" (1952)

3) A. Danielsson, Geochim. Cosmochim. Acta,
1, 55-69 (1950)

4) N.L. Bowen, J. Geology, 48 [3] 225-74(1940)

5) W. Jander und E. Hoffmann, Z. Anorg. $U$. Allg. Chem., 200, 245-56 (1931)

6) W. Jander, Z. Anorg. U. Allg. Chem., 161, 1-30 (1927)

7) W. Maskill, G.H. Whiting and W.E.S. Turner, J. Soc. Glass Technology, 16, 94-110 (1932)

8）小松和蔵, 日化誌, 74 [8] 601-608 (1953)

9) R.H. Bogue, "The Chemistry of Portland Cement" 2nd ed. (1955)

10) W.E. Ford, "Danas Textbook of Mineralogy" 4th ed. (1932)

( $2 / 8 / 58$ 受付, $4 / 9 / 58$ 再受付)

\title{
高誘電率磁器中の超音波伝播速度と 弾性常数の溫度依存性
}

\author{
岡 崎 清・河野隆介 \\ (防衛大学)
}

\section{Temperature Dependence of Elastic Constants and the Velocity of Propagation of Ultrasonic Waves in High Permittivity Ceramics}

By KIYOSHI OKAZAKI and RYUSUKE KŌNO

(Defence Academy, Japan)

In order to work out the elastic constants and their temperature dependence of high-permittivity ceramics the velocity of propagations of ultrasonic waves were studied using the rotating method which measures the angles of total reflection of insident beam by rotating the specimen. From the results the velocities of transvers and longitudinal waves and thus the elastic constants may be worked out.

The following measurements were carried out :

(1) The velocities of longitudinal and transvers waves of the frequency of $5 \mathrm{MC}$ in Barium Titanate were measured at the temperatures between $10^{\circ}$ and $140^{\circ} \mathrm{C}$. From the values obtained the temperature dependency of Young's modulus, Poisson's ratio, Lamé's constant, bulk modulus, and compressibility were worked out. The measurements were extended to a binary system, $\mathrm{BaTiO}_{3}-\mathrm{BaSnO}_{3}$.

(2) The same measurements were carried out with $\mathrm{TiO}_{2}, \mathrm{CaTiO}_{3}, \mathrm{NiSnO}_{3}, \mathrm{CuZrO}_{3}$, etc., with a result that the velocities in $\mathrm{TiO}_{2}$ and various titanates were in the range of $7000 \sim 9000 \mathrm{~m} / \mathrm{sec}$.

(3) The elastic constants of Barium Titanates showed the slight fluctuations according to the method of preparing the specimens, which probes that this simple method is accurate enough to detect such small differences.

The present method seems to be very convenient for the measurement of elastic constants of other ceramic materials whose mechanical properties are important for practical use.

緒言

$\mathrm{BaTiO}_{3}$ 系磁器は電気音響変成器として広く用いら れているが，この弾性的性質を明らかそすることは工 学的応用の見地から重要なことである. $\mathrm{BaTiO}_{3}$ 磁器 のヤング率沉ついては, 分極した磁器の共振周波数か 5, 比較的簡単飞求められるが，異方性を考慮に入れ
ると，厳密には相当困難となる ${ }^{11}$ 。さらとポアソン比 の測定には特殊の形状の試料を準備しなければなら ないので不便である. 分極しない全く等方性と考兄ら れる $\mathrm{BaTiO}_{3}$ 磁器中の超音波伝播速度（縦波と横波） を測定すれば, ヤング率, ポアソン比, 圧縮率等の弾 性常数はすべて求められ, 磁器の力学的性質を知る上 